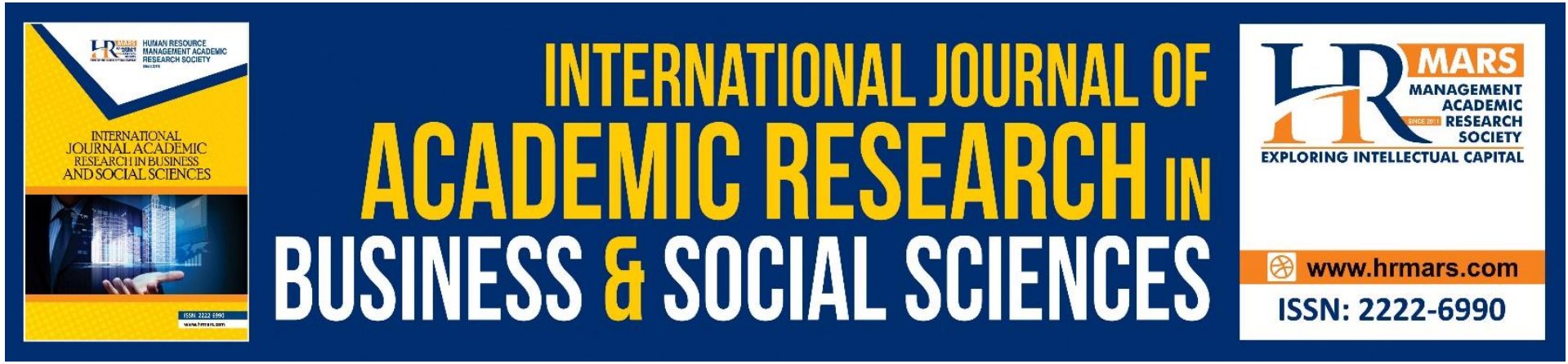

\title{
Language Learning Strategies Used for Enhancing Reading Skills Among Year 6 Pupils of A Primary School in Selangor
}

Aizuddin Rojalai, Jeniffer Shella Susaie, Lavaniya Balaraman, Sasi Rekha Manoharan, Zuraida Mustafa, Harwati Hashim

To Link this Article: http://dx.doi.org/10.6007/IJARBSS/v11-i6/10044 DOI:10.6007/IJARBSS/v11-i6/10044

Received: 12 April 2021, Revised: 15 May 2021, Accepted: 26 May 2021

Published Online: 21 June 2021

In-Text Citation: (Rojalai et al., 2021)

To Cite this Article: Rojalai, A., Susaie, J. S., Balaraman, L., Manoharan, S. R., Mustafa, Z., \& Hashim, H. (2021). Language Learning Strategies Used for Enhancing Reading Skills Among Year 6 Pupils of A Primary School in Selangor. International Journal of Academic Research in Business and Social Sciences, 11(6), 1186-1195.

Copyright: (c) 2021 The Author(s)

Published by Human Resource Management Academic Research Society (www.hrmars.com)

This article is published under the Creative Commons Attribution (CC BY 4.0) license. Anyone may reproduce, distribute, translate and create derivative works of this article (for both commercial and non-commercial purposes), subject to full attribution to the original publication and authors. The full terms of this license may be seen

at: http://creativecommons.org/licences/by/4.0/legalcode

Vol. 11, No. 6, 2021, Pg. 1186 - 1195

http://hrmars.com/index.php/pages/detail/IJARBSS

JOURNAL HOMEPAGE

Full Terms \& Conditions of access and use can be found at http://hrmars.com/index.php/pages/detail/publication-ethics 


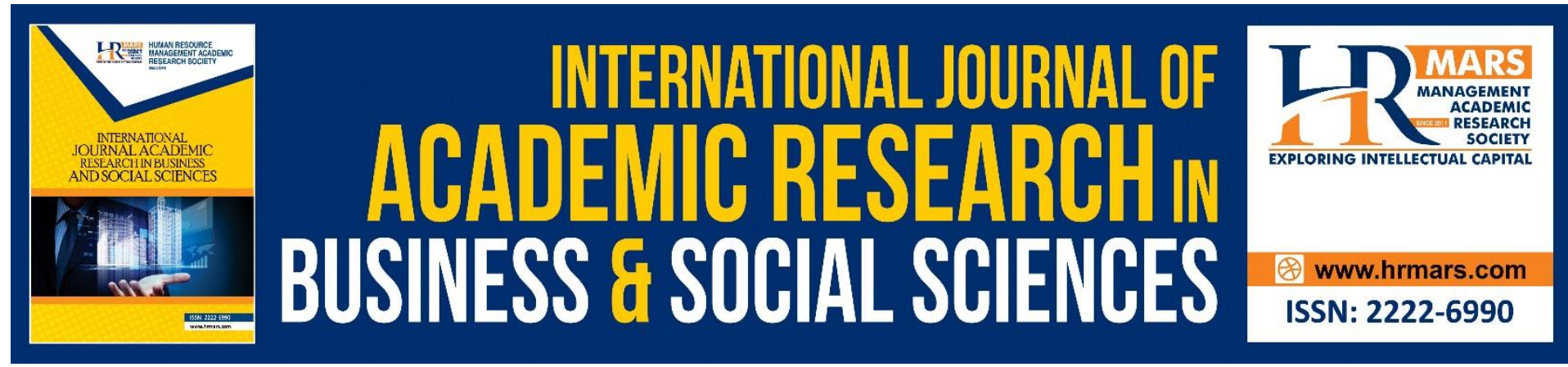

\title{
Language Learning Strategies Used for Enhancing Reading Skills Among Year 6 Pupils of A Primary School in Selangor
}

\author{
Aizuddin Rojalai, Jeniffer Shella Susaie, Lavaniya Balaraman, \\ Sasi Rekha Manoharan, Zuraida Mustafa, Harwati Hashim \\ Faculty of Education, University Kebangsaan Malaysia
}

\begin{abstract}
Learning strategies allude to a bunch of abilities that students use to comprehend various tasks. Thusly, they can pick and adequately utilize the suitable method to achieve tasks or meet specific learning objectives. Learning strategies are important in language learning especially Learning English as a second language in Malaysia because they are the tools that influence the way students learn to be active, involve which is needed for developing communicative competence among students. The primary objective of the present study is to identify the language learning strategies used for reading skills for 50 pupils of year 6 of a primary school from Selangor. This research employed a survey as an instrument by Cohen \& Oxford which is a quantitative study. The finding indicates that the learning styles provide more predictability in the strategies used.
\end{abstract}

Keywords: Language Learning Strategies, Communicative Competence, Reading Skills, Young Learners

\section{Introduction}

In Malaysia, primary schools are following the Primary School Standards-based Curriculum also known as KSSR which ensures every pupil acquires six attributes which are knowledge, thinking skills, leadership skills, bilingual proficiency, ethics, spirituality, and national identity (Musa, 2017). In addition, Barghi et al (2017) stated that this curriculum aims to ensure the students are developed holistically with sound knowledge, skills, and values. Therefore, pupils are being educated holistically by integrating $21^{\text {st }}$-century skills such as interpersonal skills, intrapersonal skills, and communication skills, creative and innovative skills. Moreover, Musa (2017) stated teachers are using many types of teaching and learning strategies to cater to the pupils with adequate skills so that the pupils are being developed as wholesome and are competitive enough worldwide. Besides that, this curriculum emphasizes four skills which are reading, writing, arithmetic, and reasoning (Kamarulzaman \& Hashim, 2018). As been mentioned in the curriculum, reading skill is an important skill that pupils are required to master which is aligned with the education policy.

Sulaiman et al (2015) mentioned according to the standard documents for English lessons, few skills are being emphasized such as listening, speaking, reading, writing, 
grammar, and language arts. In English classes, reading skill is a crucial skill as it plays as a bridge to other skills which will make the students fluent in the writing and speaking skills. Krashen (2007) said a good reader will become a competent user in other skills such as writing, speaking, and vocabulary acquisition. Sulaiman et al (2015) also stated that the teachers who conduct the reading classes will begin the reading classes with phonic lessons in fun-filled ways, followed by channelling opportunities to apply the phonic skills throughout the reading practices, showing the understanding of reading texts using the dictionary skills, word recognition, and word attack skills which are used to construct the meaning of the sentences. Apart from that, these skills are significant for the pupils to read independently for information and enjoyment purposes as well as the pupils are required to attain this level by Year 6. The pupils' level of performance in the reading skills will be measured using the band system to indicate their progress in the learning process which is from Band 1 to Band 6.

Therefore, the teachers use various language learning strategies to ensure the pupils can perform well in the reading skills. Language learning strategies are being used to boost the pupils' motivation and interest in mastering the skills. According to O'Malley et al (1990), there are three classifications for learning strategies which are cognitive, metacognitive, and social. He elaborated metacognitive language learning is about self-management such as setting goals, monitoring, and self-evaluating. On the other hand, cognitive language learning is about dealing with information such as obtaining, differencing meaning from context, using a dictionary, retain the information using memorization, repetition, and retrieving it. Social learning strategy is about cooperating with classmates and teachers. In addition, Al (2012) stated a good language learner is someone who can identify the best language learning strategy for their selves, as well as monitor the level of their achievement and does selfevaluation. He also said few factors are being considered when choosing the language learning strategies such as motivation, gender, cultural background, attitudes and belief, types of tasks, age, learning styles, and tolerance of ambiguity.

There are few types of reading skills steps that are to help the language learners to reach the objectives. Kennedy \& Keatley (2006), explained a few steps to follow which are to help the pupils master the reading skills more effectively and efficiently such as previewing the titles, sub-topics, captions on the photo, predicting, skimming, and scanning, guessing from context, and paraphrasing. On the other hand, Longwood (2006) suggested the following strategies for reading skills which are skim, guess the meaning, thinking about the prior knowledge about a certain topic, skipping the words which are less understood, and doing predictions as well revising the predictions. Furthermore, Davies (1995) classifies the types of reading as such receptive reading which is for narrative reading, reflective reading which is based on reflection, skim reading which is to get the gist of the text, and lastly, scanning or finding specific information which aids the pupils to recognize the types reading materials.

Pupils have the freedom to choose the right and perfect reading strategies that suits them in achieving the highest level of performance in reading skills. However, the foremost pupils should know the purposes of the reading skills before they brush off the skill. According to Rivers \& Temperley (1978) recommended that there are seven main purposes as to gather information, to obtain instructions about certain work, to act in a play, to play a game or do a puzzle, to keep in touch with friends, to know about surrounding and also for enjoyment purpose. Hence, the students need to set their goals and purposes in mastering this skill before recognizing the suitable language learning strategies for themselves. The language learning strategies help the pupils to improve their English proficiency in reading skills 
whereby the pupils will be able to comprehend the meaning of the text, guessing the vocabulary from the text, making generalization out of the reading materials, finding the similar meaning of words as well as identifying the style of reading texts being written.

Therefore, the purpose of this paper is to identify the best language learning strategies for reading skills among Year 6 pupils. The findings from this research will be helpful for the teachers to recognize the language learning strategy for reading skill for a certain group of students as well as this paper will assist the teachers to plan their reading lesson plans which are suitable to their pupils' needs', interest, level, and ability. Apart from that, this research also gives benefit to the participants to recognize their suitable language learning strategy for their reading skills.

\section{Literature Review Learning Strategies}

As we are learning languages or any other subject, there must be few strategies that we need to do to master those particular things. This is also included learning the English language especially those whose English is not their native language or L1. Among all those language skills like speaking, listening, reading, and writing, some researchers believed that reading is the utmost important skill when it comes to training the students to widen their vocabulary or comprehend English words. As mentioned by Küçükoğlu (2013) that teaching strategies are the most crucial skill in developing students' comprehension. Therefore, to achieve the mentioned skill successfully, the teachers need to be prepared on how to project or construct the most effective reading strategies for their students. Duke \& Pearson (2005), mentioned in their article that there are six strategies that the students or learners need to acquire to become a good reader; predicting, visualizing, making connections, summarizing, questioning, and inferring. The first one is predicting. The research found out that readers tend to use their own experience to predict things that they read (Block \& Israel, 2005). Another strategy mentioned above is visualizing. Young readers' love their books with some visuals because despite attracting them to read the books, it is also can help them to recognize the text that they have read by observing the pictures. This is supported by Adler (2001) that visuals help the readers to construct their image or imagination based on what they have read. The third strategy for reading is making connections. Teele (2004) denoted in her study that by associates, readers can use their previous knowledge and connect them with the text to enhance their understanding of the text that they have read. By doing that, reading can be meaningful and purposeful to them as they understand it better.

Another strategy is summarizing the text. Adler (2001) also stated in her research that to summarize the whole and lengthy texts, one should identify the main ideas and their supporting details. When the readers have found them, it would be easier for the readers to read and the most important is they will understand the whole meaning of the text without reading it as a whole. Second last strategy mentioned here is questioning. Harvey \& Goudvis, (2010) stated that students or readers can ask themselves before, while, and after reading what is going to happen next in the story that they have read. Last but not least is inferring whereby students or readers need to read between the lines. It means students must use their knowledge thus making conclusions based on it. Serafini (2004), indicated that through inferring, students will be able to conclude, make some predictions and use the information to create the meaning from the text. 


\section{Collaborative Learning}

Many researchers have discovered that collaborative learning positively impacts the learning process since group diversity evokes a re-thinking of the intention of every participant (Vygotsky, 1978). In the sense of ESL teaching and learning, collaborative learning allows learners to develop the English language by learning from their classmates and teachers (Fekri, 2016). Collaborative learning approaches can also be carried out using different ways and techniques, such as group activities, pair work, discussion, and the use of various teaching materials. In contrast, Alanís (2018) showed that some teachers apply visual and auditory scaffolding for the development and enhancement of collaborative learning among the learners. The findings from past research suggest that teachers use various forms to implement collaborative learning, as well as acting as a guide to this study to identify the most effective ways to be used by teachers in the ESL classroom.

Since collaborative learning is something more decent in this era, it is slightly different from the traditional way of teaching. As for the traditional teaching method, teachers delivered the knowledge to the students and also acted as instructors during the teaching and learning process. In this method, researchers found out that the students become passive as they are only received the input and knowledge directly from their teachers. It is seen that during the process of teaching and learning, there will be only one way of communication whereby the teacher conducted the lesson on their own without expecting anything from their students. That is why the method of teaching has been changed from a traditional to a modern style of teaching which focused more on $21^{\text {st }}$-century learning whereby teachers will facilitate the students and learners do the work collaboratively with their friends.

\section{Reading Skill}

Reading is one of the most important skills that students must require in school when learning English as their second language. Cohen (1990) in her study revealed that the definition of reading skill is a mental process that the readers used to complete the task successfully. In Malaysia, there are four important skills like listening, speaking, reading, and writing, and all of these skills must be taught accordingly so that the students can master all of them before completing their school terms. In the ESL context, reading not only support all those four skills but it is also helping the students who are lacked in vocabulary to help them in learning language effectively. Students must understand how to learn via reading to function in today's literate culture and communicate effectively. Reading has been characterized as an active activity in which readers switch between information sources, build meaning and tactics, assess their understanding, and utilize social context to reflect their reaction (Walker, 2000). According to research conducted in the United States, a person's ability to read effectively is strongly connected to how much he or she may achieve in both personal and professional life (Block \& Israel, 2005).

Despite its significance, reading is one of the most difficult subjects in the school system. It was claimed by (May, 2001) that a reader should concentrate not only on every single word in the text but also on the semantics of the text. Meanwhile, many language learners wrongly believe that reading is primarily to learn new vocabulary. The everincreasing need for high levels of literacy in our technology world exacerbates the situation (Harvey \& Goudvis, 2010). Students' opinions toward the goals for reading impact their ability to read as well. Students must learn to read critically or analytically if they are to get the most out of the information presented to them. The notion here is that when we read anything, we are trying to figure out what the author's aim is. When we read, we come into contact with 
two levels of reality: one that we can see and one that we cannot see. As a result, the goal of reading is to disclose and explain the invisible level or underlying meaning.

\section{Methodology}

\section{Research Design and Instrument}

This study was quantitative research that employed a survey research design embracing a survey questionnaire adopted and adapted from Cohen \& Oxford, (2003). The research design could fulfil the purpose of this study which is to identify reading strategies and the types of LLS implemented by learners of different proficiency levels in learning ESL. A survey method conducted allowed the researcher to obtain the needed data in a specific period (Shi, 2017). The questionnaire was made up of two sections which were Section A on the Personal Background and Section B on Reading Comprehension Problems with 20 items. Each item was led by 4 points Likert Scale between a range of 4 to 1 and the participants need to rate themselves. The score of 4 represented Strongly Agree. The score of 3 meant Agree. The score of 2 represented that the response was Disagree and the score of 1 was Strongly Disagree with the item.

\section{Population and Sampling}

This survey was conducted in one of the national primary schools which are located in a suburban area in Selangor, Malaysia. This study principally focused on upper primary school learners which were Year 6 pupils. There were two classes for that particular standard, which were comprised of mixed-ability learners. The chosen 50 learners aged 12 years old were purposely selected to participate in this study. They learn English in school as their second language and their mother tongue is either Malay or other languages. This population was chosen on their availability through the online survey which was conducted by the researcher during the lockdown period.

\section{Data Collection and Data Analysis}

The survey was carried out and administered whereby the researcher distributed the questionnaire to all participants through an online Google form. The survey questions were described and demonstrated to them before dissemination. The researcher also supervised them throughout the poles to make sure that the participants answered all items in the questionnaires and complete them. All the components in the questionnaires indicate the difficulties and problems faced by the learners in ESL reading comprehension. The data gathered from the items answered was calculated using the mean score. Descriptive statistics such as overall mean, frequency of scores, and percentage counts are used to identify the level of strategy usage.

\section{Findings \& Discussion}

This section describes the findings of the survey based on reading strategies preferred by ESL learners. The result was obtained from an online survey due to the COVID-19 pandemic. Discussion of strategies preferred by students will be further discussed in the discussion section. 


\begin{tabular}{|c|c|c|c|c|c|}
\hline \multicolumn{6}{|c|}{ Reading Skill } \\
\hline No & Strategy & $\begin{array}{l}\text { Strongly } \\
\text { Agree }\end{array}$ & Agree & Disagree & $\begin{array}{l}\text { Strongly } \\
\text { Disagree }\end{array}$ \\
\hline 1 & I can understand a minimum of 10 words in a text. & 9 & 24 & 12 & 5 \\
\hline 2 & $\begin{array}{l}\text { I read a text more than once for better } \\
\text { understanding. }\end{array}$ & 14 & 28 & 5 & 3 \\
\hline 3 & $\begin{array}{l}\text { I circle/underline the difficult words to find the } \\
\text { meaning in the dictionary. }\end{array}$ & 13 & 24 & 10 & 3 \\
\hline 4 & $\begin{array}{l}\text { I imagine the sequence of the story while reading } \\
\text { a text. }\end{array}$ & 14 & 26 & 8 & 2 \\
\hline 5 & $\begin{array}{l}\text { Pictures help me to illustrate the content of the } \\
\text { text. }\end{array}$ & 19 & 26 & 2 & 3 \\
\hline 6 & $\begin{array}{l}\text { When I read, I guess the meaning of unknown } \\
\text { words or phrases. }\end{array}$ & 11 & 28 & 9 & 2 \\
\hline & Mean score & 13 & 26 & 8 & 3 \\
\hline
\end{tabular}

Table 1: The number of ESL learners in answering the online survey

\section{Overall Analysis for reading strategies}

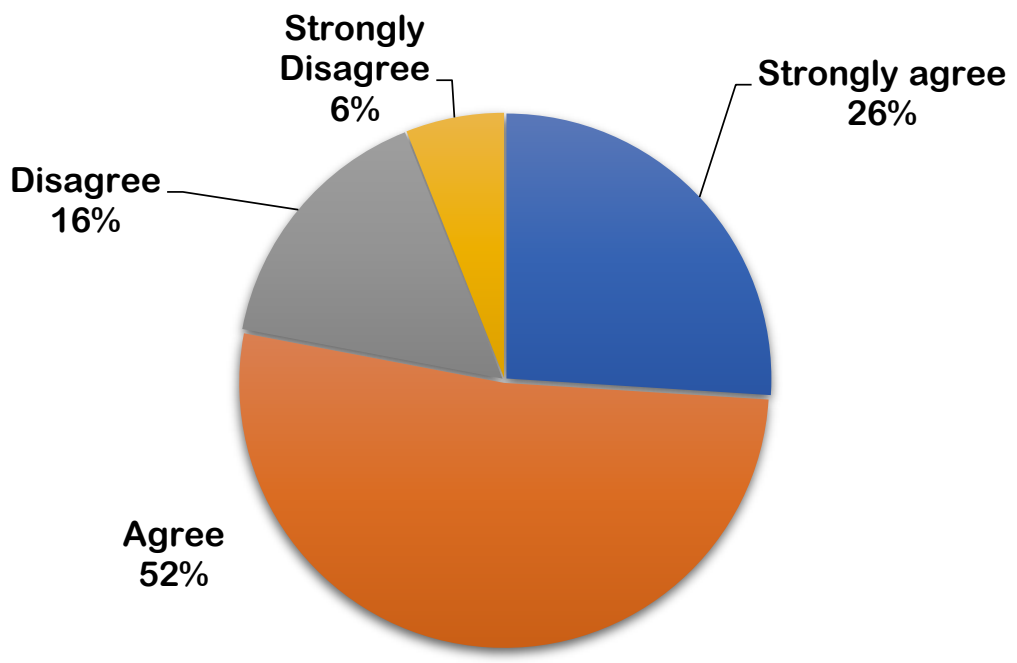

Figure 1: Overall analysis for reading strategies 
In table 1, students were asked about what are the strategies they prefer to use when reading a text. They were given six strategies and the result was quite interesting. 19 of the students which are $38 \%$ of them strongly admit that pictures help to illustrate the content of the text while reading a text ( $5^{\text {th }}$ strategy). $56 \%$ or 28 out of 50 students agree that reading more than once helps to understand better ( $2{ }^{\text {nd }}$ strategy) and able to guess the meaning of unknown words or phrases ( $6^{\text {th }}$ strategy). There were only $10 \%$ of students could not able to understand a minimum of ten words in a text ( $1^{\text {st }}$ strategy) but this was also shown useful for $48 \%$ of students who agree to the same strategy. 10 out of 50 students do not prefer to circle or underline the difficult words to find the meaning in the dictionary ( $3{ }^{\text {rd }}$ strategy) but $48 \%$ or 24 students out 50 agree that they use this strategy while reading a text. Finding also shows that $52 \%$ of students admit that they imagine the sequence of the story while reading a text ( $4^{\text {th }}$ strategy) which is also strongly supported by $28 \%$ of students.

Based on the overall result, it can be concluded that $52 \%$ which more likely half of the students agree that they used the six strategies when reading a text. The least percentage of students which is $6 \%$ did not prefer using these strategies while reading. This shows the majority of the students prefer these strategies while reading a text. It also can be sum up that the $5^{\text {th }}$ strategy which is picture illustrates the content of the text is more preferred by the students while reading a text. According to the findings, this strategy shows the highest number of students who strongly admit and the second-highest where students agree to use while reading a text. Based on Yum (2021) stated that generally, the combination of text and pictures moderate the process of understanding the meaning of a text. Besides, Wiley (2018) argued that sometimes relevant images might deceive the readers when they interpreted the understanding. Therefore, relying on one strategy does not always give a better understanding for the learners. Learners must use different strategies while reading to comprehend the text.

\section{Conclusion}

Teaching reading for the primary school students is one of the important skills that need to be highlighted because through reading, one can widen their knowledge and also the vocabulary. Some teachers tend to teach reading using the same methods such as read-aloud strategy and silent reading strategy. However, in language learning, it is not only one-man job which is the teachers' job only, but the students also need to identify which strategy that they think suit them the most. Hence, this research was able to establish a suitable language learning strategy for the participants in reading skills who were enrolled in one of the primary schools in Selangor. It can be concluded that language learning strategies are vary in every student. They must be skilful in various strategies in order to master the targeted language. The findings of the research proved that most of the primary school students preferred reading with the help of some images so that it can assist their understanding regarding the text that they are reading. Since they are all young learners, reading with the help of the images at the same time can attract their interest in reading. By doing so, the teachers can identify a suitable strategy to approach the students in reading tasks and to develop other skills as well. Likewise, the teachers can use their knowledge about their students to adjust the strategies without depending on the same old strategy.

It can be concluded that language learning strategies are vary in every student. They must be skilful in various strategies in order to master the targeted language. The findings of the research proved that most of the primary school students preferred reading with the help of some images so that it can assist their understanding regarding the text that they are 
reading. Since they are all young learners, reading with the help of the images at the same time can attract their interest in reading. By doing so, the teachers can identify a suitable strategy to approach the students in reading tasks and to develop other skills as well. Likewise, the teachers can use their knowledge about their students to adjust the strategies without depending on the same old strategy.

\section{References}

Adler, C. R. (Ed.). (2001). Put reading first: The research building blocks for teaching children to read. Jessup, MD: ED Pubs.

Alanís, I. (2018). Enhancing collaborative learning: Activities and structures in a dual language preschool classroom. Association of Mexican American Educators Journal, 12(1), 526.Available at: https://doi.org/10.24974/amae.12.1.375

Al Azmi, H. (2012). The Students' language Learning Strategies in Reading and Speaking. Al-Ta Lim Journal, 19(2), 122-133.

Barghi, R., Zakaria, Z., Hamzah, A., \& Hashim, N. H. (2017). Heritage education in the primary school standard curriculum of Malaysia. Teaching and Teacher Education, 61, 124-131.

Block, C., \& Israel, S. (2005). Reading first and beyond: The complete guide for teachers and literacy coaches. Thousand Oaks, CA: Corwin Press.

Cohen, A. D. (1990). Language learning: Insights for learners, teachers, \& researchers. NY: Newbury House Publishers

Davies, C. (1995). Extensive Reading: an expensive extravagant? ELT Journal, 4(4), $329-336$

Fekri, N. (2016). Investigating the effect of cooperative learning and competitive learning strategies on the English vocabulary development of Iranian intermediate EFL learners. English Language Teaching, 9(11), 6-12. Available at:

https://doi.org/10.5539/elt.v9n11p6

Harvey, S., \& Goudvis, A. (2010).Strategies that work teaching comprehension to enhance understanding. York, ME: Stenhouse Publishers.

Kamarulzaman, W., \& Hashim, R. (2018). Primary School Teachers' Understanding of Critical Thinking in KSSR Classroom.

Kennedy and Keatley. (2006). Teaching reading strategies for Developing Reading Skills. Retrieved on 20 May 2021 from: http://www.nclrc.org/essentials/motivating/strategies.htm

Krashen, S. (2007). Extensive reading in English as a foreign language for adolescents and young adults. The International Journal of Foreign Language Teaching, 3(2), 2329.

Küçükoğlu, H. (2013). Improving reading skills through effective reading strategies. ProcediaSocial and Behavioral Sciences, 70, 709-714.

Longwood. (2006). Strategies for Learning a Foreign Language.

May, F. B. (2001). Unraveling the seven myths of reading. US: Allyn and Bacon.

O'malley, J. M., O'Malley, M. J., Chamot, A. U., \& O'Malley, J. M. (1990). Learning strategies in second language acquisition. Cambridge university press.

Rivers, W., \& Temperley, M. (1978). A practical guide to the teaching of English as a second or foreign language. New York: Oxford University Press

Serafini, F. (2004). Lessons in comprehension explicit instruction in the reading workshop. Portsmouth, NH: Heinemann. 
Shi, H. (2017). Learning strategies and classification in education. Institute for Learning Styles Journal, 1(1), 24-36

Sulaiman, T., Ayub, A. F. M., \& Sulaiman, S. (2015). Curriculum change in English language curriculum advocates higher-order thinking skills and standards-based assessments in Malaysian primary schools. Mediterranean Journal of Social Sciences, 6(2), 494-494.

Teele, S. (2004). Overcoming barricades to reading a multiple intelligences approach. Thousand Oaks, CA: Corwin Press.

Walker, J. B. (2000). Diagnostic teaching of reading: Techniques for instruction and assessment (4th ed.). OH: Merril.

Wiley, J. (2018). Picture this! Effects of photographs, diagrams, animations, and sketching on learning and beliefs about learning from a geoscience text. Applied Cognitive Psychology.

Yum, Y. N. (2021). Effects of picture-word integration on reading visual narratives in L1 and L2. Learning and Instruction. 